\title{
INO80 wt Allele
}

National Cancer Institute

\section{Source}

National Cancer Institute. INO80 wt Allele. NCI Thesaurus. Code C142230.

Human INO80 wild-type allele is located in the vicinity of 15q15.1 and is approximately $137 \mathrm{~kb}$ in length. This allele, which encodes DNA helicase INO80 protein, plays a role in DNA helicase activity. 